\title{
The Overlooked Component in the Consumption of Counterfeit Luxury Brands Studies: Materialism - A Literature Review
}

\author{
Viet-Dung Trinh \\ Curtin University \\ E-Mail: viet.trinh@postgrad.curtin.edu.au \\ Ian Phau \\ Curtin University \\ E-Mail: ian.phau@cbs.curtin.edu.au
}

\begin{abstract}
Trade in counterfeit luxury brands is perceived as a challenging issue to the luxury industry. As such, this paper sought to explore an often overlooked component of consumer behavior in the consumption of counterfeit luxury brands - materialism. An extensive and critical literature review was conducted that included contributions from different streams of management and marketing research. While researchers has noted that materialism plays an essential role in influencing purchase intention of consumer consumption of luxury brands, little is known about its role in consumption of counterfeit luxury brands. Moreover, the concept of materialism can be further dimensionalized to pertain to the motivation of indulging in counterfeit purchases. Through further investigation of the role of materialism in the consumption of counterfeit luxury brands, this paper also opens an agenda of directions that are worthy of research and will have academic, managerial, and social policy significance.
\end{abstract}

Keywords: Materialism, Counterfeit, Luxury

\section{INTRODUCTION}

\section{Practical Background}

The marketing practice of branding luxury products can be dated back to the Roman period when Roman winemakers put unique marks on their wine amphorae (Chaudhry and Walsh, 1996). Likewise, the first practice of counterfeiting can also be 
dated back to the same period when wine merchants from Gaul copied and put those unique marks on cheap local wines and sold them as expensive Roman wine (Phillips, 2005).

Counterfeiting of luxury brands has grown steadily in the past few years, regardless of the combined efforts of individual organizations and law enforcement agencies. Anti-counterfeiting forces have relentlessly pursued legal battles in many countries in their fight against counterfeiting. Despite their efforts, the consumption of counterfeit luxury brands continues to soar, worldwide. For example, in 2007, U.S. Customs seized over $\$ 200$ million worth of counterfeit luxury brands; this was only the tip of the iceberg (BASCAP Report, 2009). In recent years, the consumption of counterfeit luxury brands continues to expand, worldwide, and is now regarded as a common act of consumption. Without reservation, counterfeiting luxury brands is one of, if not, the most critical issues for the luxury industry because it unlawfully takes advantage of the prestige of luxury brands and harms their tradition, identity, and image.

\section{Objective and Structure}

The objective of this paper is to:

- Identify theoretical gaps and opportunities for further research; and

- Draw managerial implications for the fight against the consumption of counterfeit luxury brands.

The remained of this paper is organized as follows: the second chapter provides a clear definition of counterfeiting, counterfeit luxury brands, and materialism. Following, is a comprehensive review of the academic literature regarding materialism, consumption of counterfeit luxury brands, and existing literature on materialism in the counterfeit context.

\section{TERMS AND DEFINITIONS}

By definition, counterfeiting is any unauthorized manufacturing of goods whose special characteristics, such as names, content, or signs, are registered to another party and, thus, protected as intellectual rights (Bian and Veloutsou, 2007). Counterfeit luxury brands are also known under several other names such as replicas, imitation, bogus, fakes, copy, and knock-off, and are often considered to be of poor quality (Lai and Zaichkowsky, 1999).

Richins and Dawson (1992) defined materialism as "the importance ascribed to the ownership and acquisition of material goods in achieving major life goals or 
desired states." As counterfeit luxury brands replicate versions of genuine luxury brands, the demand for such products should also be driven by the same values that consumers expect in a genuine luxury product. Previous studies on luxury brands have also indicated that consumer attitudes toward genuine luxury brands may serve a social adjustment function, a value-expressive function, or both (Shavitt, 1989). For example, a person might purchase a Gucci bag because the brand reflects her personality (value-expressive function) or because it stands for a status symbol that helps her fit into a specific social group (social adjustment function), or for both reasons. As such, these functions of attitude are postulated to be connected to materialism.

\section{LITERATURE REVIEW}

\section{Methodology}

Despite the fact that the first study on counterfeiting was published more than 30 years ago (Hansen, 2009; Staake, Thiesse, and Fleisch 2009), counterfeiting research has yet to be established as an independent research stream. Literature on counterfeiting spreads across various streams of business-related research including management, logistics, marketing, economics, and others. Because the objective of this study was to depict the role of materialism in current knowledge and the consumption of counterfeit luxury brands, journals in the area of sociology, marketing, consumer research, and management were given a more explicit focus. Works in other disciplines, such as law or business ethics, are only mentioned when they hold significant influence on this subject.

This study began with an extensive search in electronic journal databases (ProQuest, ScienceDirect, Emerald Insight) for the keywords that included "materialism," "counterfeit," and "luxury." The initial search returned over 59,000 findings for "counterfeit," 628 for the combination of "counterfeit" and "luxury," 32 for "counterfeit" and "materialism," and only 11 results for all three key words. After eliminating unrelated articles, 67 studies that concentrated on counterfeits of luxury brands or materialism of consumers were selected for further review. References and bibliographies from these studies were cross-referenced to identify further contributions from other sources. In the end, 36 journals were selected for inclusion in this paper. In addition to academic papers, reports from trade magazines and industry organizations, such as BASCAP (Business Actions to Stop Counterfeit and Piracy), were also included to provide the primary data upon which other academic papers were based. 
This paper will first present a section of general descriptions of the following

- General descriptions of the phenomenon

1. Materialism

2. Consumption of counterfeit luxury brands

- Materialism in existing counterfeit luxury brands literature

\section{General Descriptions of the Phenomenon}

\section{- Materialism}

The oldest theory that attempted to explain consumers' demand for luxury brands was the theory of conspicuous consumption (Veblen, 1899). According to this theory, the demand for luxury brands is motivated by consumers' desires for social status or esteem, which can only be achieved by acquiring and displaying luxury goods and wealth. Thus, the social esteem of consumers, rather than economical value or physiological utility of goods, drives conspicuous consumption (Veblen, 1899; Mason, 2001; 1981). Materialistic consumers tend to consume more than other consumers, with a clear intention to consume products that generate social recognition or status for the owner (Mason, 2001). Further, these individuals often display acquired goods to distinguish themselves from others. This has been portrayed thoroughly by several studies on conspicuous and consumption of luxury brands (Dubois and Paternault, 1995; Campbell, 1995; Corneo and Olivier, 1997; Faure and Fang, 2008; Chaudhuri and Majumdar, 2006). Because of the wealth and status that is signaled via the use of luxury brands (Mason, 1998), highly materialistic consumers, without the financial capacity to achieve their ambitions, are easily tempted to buy counterfeit luxury brands.

\section{- Consumption of Counterfeit Luxury Brands}

Most general information about the consumption of counterfeit luxury brands can be found in trade magazines (The Economist, 2004; Business Week, 2005; The Guardian, 2010) and reports published by industry organizations (BASCAP Report, 2009). Further, articles from magazines generally outline examples of spectacular cases or seizures in selected markets and discuss the magnitude of luxury brand counterfeiting, while reports from industry organizations illustrate the existence of counterfeits and market research data in different regions of the world.

In academic journals, from the first publication in the 1970s until recently, luxury brand counterfeiting had been described as cheaper and lower quality copies of authentic brands. The quality of counterfeit luxury brands has improved dramatically 
compared to 10 years ago and this activity has also affected the demographic of potential consumers. With improvements in manufacturing processes and greater attention to detail, counterfeit luxury brands are no longer the cheaper and lower quality copies of genuine ones (Penz and Stottinger, 2005). In fact, some counterfeit goods are easily mistaken for the genuine product, even to the trained eye. Furthermore, the trade of counterfeit goods has also increased exponentially with extensive distribution and logistics networks (Wilcox, Kim, and Sen, 2009), especially on the Internet. Because of the excellent quality, cheaper price, and relative ease of access, people who actively seek and purchase counterfeit luxury brands are no longer limited to those who cannot afford the genuine ones (BASCAP Report, 2009).

\section{Materialism in Existing Counterfeit Luxury Brand Literature}

In the beginning, most studies on counterfeiting focused on the supply side, while there was a lack of research that examined the consumer perspective. As such, it was not until must later in the counterfeit literature that materialism was even mentioned. For example, in 1995, Wee et al. (1995) published an article in the International Marketing Review that examined materialism as a key component. However, the study found that, whether a person was materialistic, risk taking, novelty seeking, or not, had no effect on buying intention. Later, in an extensive review of the counterfeit trade, published in 2009, Staake et al. (2009) presented an exclusive list of literature that was related to the subject dated from 1978 to 2008. Among these studies, there was only one paper that had investigated the consumption of counterfeits using materialism as a key component (Furnham and Valgeirsson, 2007). Nevertheless, the findings of this study confirmed only one in three material values material centrality - as a predictor of buying intention.

Further exploration into this subject using electronic databases only resulted in a few more published papers, dated from 2008 to 2010, that have employed materialism scales and models in their research (Phau, Sequeira, and Dix, 2009; Swami, Chamorro-Premuzic, Furnham, 2009). These include Furnham and Valgeirsson's paper (Furnham and Valgeirsson, 2007) and three papers that employed either materialism scale designed by Richins and Dawson or Belk's materialism traits in their study of counterfeit of luxury brands. Although both models are highly regarded by researchers, neither has proven that materialism is a solid force in predicting the consumption of counterfeit luxury brands (Furnham and Valgeirsson, 2007; Phau, Sequeira, and Dix, 2009; Swami, Chamorro-Premuzic, Furnham, 2009). 
On the other hand, Wan et al. (2009) employed an adapted version of Richins' materialism scale in their CD piracy study and found significant results. Furthermore, a recent study in Indonesia ( $\mathrm{Lu}$ and Lu, 2010), also using Richins' scales, found that materialism is positively correlated with consumers' ethical judgments. This suggests that an individual with high level of materialism is more likely to be involved in questionable consumer practices.

With only a handful of studies on materialism in the context of counterfeiting of luxury brands, it is difficult to bring a conclusion on the role of materialism in illicit consumer behaviors. Given the importance of materialism in the consumption of luxury brands, this is surely an area that requires further investigation.

\section{DISCUSSION}

\section{Research Gaps}

Given the widespread of counterfeits, it comes as a surprise that there is a relative dearth of literature in this area. It is an even bigger surprise to see that only a few studies have used materialism as a key component. Further, previous studies on consumption of luxury brands have indicated that materialism plays an important role in influencing the buying intentions of consumers. Because the nature of counterfeiting must copy a trademarked brand in order to sell itself, counterfeiting often targets luxury products that have a high brand value. Therefore, materialism should also play a significant role in influencing buying intention of counterfeit luxury brands.

Moreover, previous studies that used or adapted Richin's materialism scale have found inconclusive results (Wilcox, Kim, and Sen, 2009; Swami, Chamorro-Premuzic, Furnham, 2009; Wan et al., 2009; Lu and Lu, 2010). Reasons such as cultural background and income level may explain this occurrence; however, it could also be because Richin's scales were originally developed to measure the materialistic level of consumer consumption of authentic brands, not counterfeits. While consumption of authentic luxury brands is driven by conspicuousness and the urge to be distinguished (Csikzentimihalyi and Rochberg-Halton, 1981; Kaikati and LaGarce, 1980), materialistic consumers, who buy counterfeits of luxury brand, seek social recognition, status (Wilcox, Kim, and Sen, 2009; Swami, Chamorro-Premuzic, and Furnham, 2009), and, in a way, become more similar to authentic brand users. Thus, to measure the materialistic level of consumers in the counterfeit of luxury brand context, the materialism scale must be able to measure, not only material conspicuousness, but also status and material distinctiveness. 


\section{Managerial Implications}

Managerially, the lack of study on materialism may have obstructed organizations' planning of more effective anti-counterfeiting strategies. Further research into this subject will help management of authentic brands by providing a better understanding of what drives consumers toward counterfeits of luxury brands so that they are able to design better anti-counterfeit strategies.

\section{SUMMARY AND OUTLOOK}

The development of counterfeit of luxury brands remains a substantial threat to the luxury industry. Against this background, this paper provided a literature review to shed light on an often overlooked component based on its importance. The diversity of the counterfeit phenomenon underlines the need for further research in this area. Because materialism is a significant factor that influences buying intention of consumers and existing research findings are still far from concrete, further investigation is warranted. From a managerial perspective, it may be helpful to understand the relevant influential factors in order to assist the development of company-specific measures in the fight against counterfeiting.

\section{REFERENCES}

Anonymous. (2004, Jan 22). Counterfeited goods: "Psst. Wanna real Rolex". The Economist. $\quad$ Retrieved June 14, 2011, from http://www.economist.com/node/2373371

BASCAP Report. (2009). Research Report on Consumer Attitudes and Perceptions on Counterfeiting and Piracy. Retrieved June 14, 2011, from http://www.iccwbo.org/bascap.

Bian, X. and Moutinho, L. (2009). An investigation of determinants of counterfeit purchase consideration. Journal of Business Research, 62(3), 368-378.

Bian, X. and Veloutsou, C. (2007). Consumers' attitudes regarding non-deceptive counterfeit brands in the UK and China. Journal of Brand Management, 14(3), 211-222.

Balfour, F., Matlack, C., Barrett, A., Capell, K., Roberts, D., Wheatley, J., Symonds, W., Magnusson, P., and Brady, D. (2005, February 6). Fakes! Business Weeks. Retrieved June 14, 2011, from http://www.businessweek.com/magazine/content/05_06/b3919001_mz001.htm Campbell, C. (1995). Conspicuous Confusion? A Critique of Veblen's Theory of Conspicuous Consumption. Sociological Theory, 13(1), 37-45. 
Chaudhry, P. E. and Walsh, M. G. (1996). An assessment of the impact of counterfeiting in international markets: the paradox persists. Columbia Journal of World Business, 31(3), 34-48.

Chaudhuri, H. R. and Majumdar, S. (2006). Of Diamonds and Desires: Understanding Conspicuous Consumption from Contemporary Marketing Perspective. Academy of Marketing Review, 2006(11), 2-18.

Cheung, W. and Prendergast, G. (2006). Buyer's perceptions of pirated products in China. Marketing Intelligence \& Planning, 24(5), 446-462.

Chuchinparkarn, S. (2003). Consumption of Counterfeit Goods in Thailand: Who Are the Patrons? European Advances in Consumer Research, 6(2003), 48-53.

Corneo, G. and Olivier, J. (1997). Conspicuous Consumption, Snobbism and Conformism. Journal of Public Economics, 66(1), 55-71.

Csikzentimihalyi, M. and Rochberg-Halton, E. (1981). The Meaning of Things: Domestic Symbols and the Self. Cambridge University Press: Cambridge.

Dubois, B. and Paternault, C. (1995). Observation - Understanding the world of international Luxury brands: the dream formula. Journal of Advertising Research, 35(4), 69-76.

Faure, G. O. and Fang, T. (2008). Changing Chinese values: Keeping up with paradoxes. International Business Review, 17(2008), 194-207.

Furnham, A. and Valgeirsson, H. (2007). The effect of life values and materialism on buying counterfeit products. The Journal of Socio-Economics, 36(5), 677-685.

Green, R. T. and Smith, T. (2002). Executive insights: countering brand counterfeiters. Journal of International Marketing, 10(4), 89-106.

Grossman, G. M. and Shapiro, C. (1988). Counterfeit-product trade. American Economic Review, 78(1), 59-75.

Staake, T., Thiesse, F., and Fleisch, E. (2009). The emergence of counterfeit trade: a literature review. European Journal of Marketing, 43(3), 320-349.

Hilton, B., Choi, C. J., and Chen, S. (2004). The ethics of counterfeiting in the fashion industry: quality, credence and profit issues. Journal of Business Ethics, 55(4), 343-352.

Kaikati, J. G. and LaGarce, R. (1980). Beware of international brand piracy. Harvard Business Review, 58(2), 52-58.

Lai, K. and Zaichkowsky, L. (1999). Brand Imitation: Do the Chinese Have Different Views? Asia Pacific Journal of Management, 16(2), 179-192.

Lu, L. C. and Lu, C. J (2010). Moral Philosophy, Materialism and Consumer Ethics: An Exploratory Study in Indonesia. Journal of Business Ethics, 94(2), 193-210. 
Mason, R. (1981). Conspicuous Consumption: A Study of Exceptional Consumer Behavior. England: Gower.

Mason, R. (1998). The Economics of Conspicuous Consumption. MA: Edward Elgar.

Mason, R. (2001). Conspicuous consumption: A literature review. European Journal of Marketing, 18(3), 26-39.

Nia, A. and Zaichkowsky, J. L. (2000). Do counterfeits devalue the ownership of luxury brands? Journal of Product \& Brand Management, 9(7), 485-497.

Penz, E. and Stottinger, B. (2005). Forget the Real Thing - Take the Copy! An Explanatory Model for the Volitional Purchase of Counterfeit Products. Advances in Consumer Research, 32, 568-575.

Phau, I., Sequeira, M., and Dix, S. (2009). To buy or not to buy a "counterfeit" Ralph Lauren polo shirt: The role of lawfulness and legality toward purchasing counterfeits. Asia-Pacific Journal of Business Administration, 1(1), 68-80.

Phillips, T. (2005). Knockoff: The Deadly Trade in Counterfeit Goods. Sterling, VA: Kogan Page.

Richins, M. L. and Dawson, S. (1992). A consumer values orientation for materialism and its measurement: Scale Development and Validation. Journal of Consumer Research, 19(Dec), 303-316.

Shavitt, S. (1989). Products, Personalities and Situations in Attitude Functions: Implications for Consumer Behavior. Advances in Consumer Research, 16, 300-305.

Staake, T., Thiesse, F., and Fleisch, E. (2009). The emergence of counterfeit trade: a literature review. European Journal of Marketing, 43(3), 320-349.

Swami, V., Chamorro-Premuzic, T., and Furnham, A. (2009). Faking it: Personality and individual difference predictors of willingness to buy countefeit goods. The Journal of Socio-Economics, 38(5), 820-825, 2009.

Tims, A. (2010, March 19). PayPal not so friendly over return of fake goods. The Guardian. $\quad$ Retrieved June 14, 2011, from http://www.guardian.co.uk/money/2010/mar/19/paypal-return-fake-goods

Veblen, T. B. (1899). The Theory of the Leisure Class. Boston: Houghton Mifflin.

Wan, W. W. N., Luk, C. L., Yau, O. H. M., Tse, A. C. B., Sin, L. Y. M., Kwong, K. K., and Chow, R. P. M. (2009). Do traditional Chinese Cultural Values Nourish a Market for Pirated CDs? Journal of Business Ethics, 88(1), 185-196.

Wee, C., Tan, S., and Cheok, K. (1995). Non-Price Determinants of Intention to Purchase Counterfeit Goods: An Exploratory Study. International Marketing Review, 12(6), 19-46. 
Wilcox, K., Kim, H. M., and Sen, S. (2009). Why do consumers buy counterfeit luxury brands. Journal of Market Research, 46(2), 247-259.

\section{APPENDICES}

Table 1 Background of Consumption of Counterfeit Luxury Brands

\begin{tabular}{lll}
\hline \multicolumn{1}{c}{ Author(s) } & Year & \multicolumn{1}{c}{ Short description } \\
\hline Hansen & 1978 & Evidence of the global consumption of counterfeits. \\
\hline Kaikati can LaGrace & 1980 & Discussion of different forme of brand piracy. \\
\hline Grossmann and Shapiro & 1988 & $\begin{array}{l}\text { Non-deceptive counterfeiting was described as a } \\
\text { disaggregation of brand and product. }\end{array}$ \\
\hline & $\begin{array}{l}\text { The study identified that various non price determinants } \\
\text { have significant impact on consumers' purchase intention } \\
\text { toward counterfeit goods and include psychographic } \\
\text { Wee } \text { et al. }\end{array}$ \\
& $\begin{array}{l}\text { (attitudes toward counterfeiting, brand status, and novelty } \\
\text { seeking), demographic (age, educational attainment, and } \\
\text { household income), and product-attributes (appearance, } \\
\text { durability, image, perceived fashion content, purpose, and } \\
\text { quality) variables. The study indicated that whether a } \\
\text { person was materialistic, risk taking, novelty seeking or not } \\
\text { had no effect on his or her intention to purchase } \\
\text { Counterfeit products. }\end{array}$ \\
\hline
\end{tabular}

A paper on research trends in counterfeits that provided an

Chaudhry and Walsh

1996 overview of the legal framework, a review of different anti-counterfeiting strategies, and a summary of techniques used to distinguish between real and fake goods.

\begin{tabular}{|c|c|c|}
\hline Nia and Zaichkowsky & 2000 & $\begin{array}{l}\text { Viewpoints of luxury brand owners toward counterfeit } \\
\text { luxury goods. }\end{array}$ \\
\hline Green and Smith & 2002 & Summary of the counterfeit trade. \\
\hline Chuchinparkarn & 2003 & $\begin{array}{l}\text { A study on counterfeiting in Thailand from a consumer } \\
\text { perspective. }\end{array}$ \\
\hline Hilton et al. & 2004 & $\begin{array}{l}\text { Descriptions of various types of counterfeiting that take } \\
\text { place in the luxury clothing industry. }\end{array}$ \\
\hline Penz and Stottinger & 2005 & $\begin{array}{l}\text { Survey among } 1,040 \text { respondents via the Theory of } \\
\text { Planned Behavior to systematize past findings in the field } \\
\text { and determine key drivers for the demand of counterfeits. }\end{array}$ \\
\hline
\end{tabular}




\section{Table 1 Background of Consumption of Counterfeit Luxury Brands (Continued)}

\begin{tabular}{|c|c|c|}
\hline Author(s) & Year & Short description \\
\hline Cheung and Prendergast & 2006 & $\begin{array}{l}\text { Survey among } 1,152 \text { buyers in two categories counterfeit } \\
\text { products. Heavy and light buyers of pirated clothing and } \\
\text { accessories have similar demographic and attitudinal } \\
\text { profiles and were mainly attracted by the appearance of the } \\
\text { product. Both product categories were rated less positively } \\
\text { on their ethical and legal dimensions and on after-sales } \\
\text { service. }\end{array}$ \\
\hline Bian and Moutinho & 2009 & $\begin{array}{l}\text { The study anticipated and explored the effects of } \\
\text { consumer-perceived brand image, perceived risk, product } \\
\text { knowledge, product involvement, and consumer } \\
\text { demographic variables. The results showed that, among the } \\
\text { tested variables, brand personality performed the best in } \\
\text { determining consideration of the counterfeit brands. In } \\
\text { general, demographic variables and product involvement } \\
\text { do not appear to be significantly influential. }\end{array}$ \\
\hline Swami et al. & 2009 & $\begin{array}{l}\text { Survey among } 237 \text { adults in the UK. Results indicated that } \\
\text { attitudes toward counterfeiting were the strongest } \\
\text { predictors of purchase intention. Material values predicted } \\
\text { purchase intention directly and indirectly via attitudes } \\
\text { toward counterfeiting }\end{array}$ \\
\hline Staake et al. & 2009 & $\begin{array}{l}\text { A detailed review of literature that studies counterfeiting } \\
\text { from } 1978 \text { to } 2008 \text {. }\end{array}$ \\
\hline Wilcox et al. & 2009 & $\begin{array}{l}\text { This research demonstrated that consumers' desire } \\
\text { counterfeit luxury brands because of the social motivations } \\
\text { underlying their luxury brand preferences. }\end{array}$ \\
\hline Wan et al. & 2009 & $\begin{array}{l}\text { Survey among } 300 \text { respondents in Hong Kong. The study } \\
\text { found that face consciousness increased materialism and } \\
\text { risk aversion and thereby produced a favorable } \\
\text { deontological judgment of pirated CDs. }\end{array}$ \\
\hline $\mathrm{Lu}$ and $\mathrm{Lu}$ & 2010 & $\begin{array}{l}\text { Survey among } 230 \text { Indonesian respondents. Analytical } \\
\text { results indicated that Indonesians with high materialism } \\
\text { and relativism were more likely to engage in actions that } \\
\text { were questionable but legal. }\end{array}$ \\
\hline
\end{tabular}


Table 2 Materialism in Counterfeit Literature

\begin{tabular}{|c|c|c|}
\hline Author(s) & Year & Short description \\
\hline Wee et al. & 1995 & $\begin{array}{l}\text { The study found that various non-price determinants had a } \\
\text { significant impact on consumers' purchase intentions } \\
\text { toward counterfeit goods, that included psychographic } \\
\text { (attitude toward counterfeiting, brand status, and novelty } \\
\text { seeking), demographic (age, educational attainment, and } \\
\text { household income), and product-attribute (appearance, } \\
\text { durability, image, perceived fashion content, purpose, and } \\
\text { quality) variables. The study indicated that whether a } \\
\text { person was materialistic, risk taking, novelty seeking or } \\
\text { not had no effect on his or her intention to purchase } \\
\text { counterfeit products. }\end{array}$ \\
\hline Furnham and Valgeirsson & 2007 & $\begin{array}{l}\text { Survey among } 102 \text { adults, based on Richins' materialism } \\
\text { scales, Schwartz value inventory, and questions about } \\
\text { belief of counterfeit. Belief of counterfeit was found to be } \\
\text { a strong influence, while materialism only contributed to } \\
\text { some variance and Schwartz value inventory did not have } \\
\text { any influence. }\end{array}$ \\
\hline Swami et al. & 2009 & $\begin{array}{l}\text { Survey among } 237 \text { adults in the UK. Results indicated } \\
\text { attitudes toward counterfeiting were the strongest } \\
\text { predictors of purchase intention. Material values predicted } \\
\text { purchase intention directly and indirectly via attitudes } \\
\text { toward counterfeiting. }\end{array}$ \\
\hline Wan et al. & 2009 & $\begin{array}{l}\text { Survey among } 300 \text { respondents in Hong Kong. The study } \\
\text { found that face consciousness increased materialism and } \\
\text { risk aversion, thereby producing a favorable deontological } \\
\text { judgment of pirated CDs. }\end{array}$ \\
\hline Phau et al. & 2009 & $\begin{array}{l}\text { Survey among } 202 \text { students in Australia. The study found } \\
\text { that attitudes did not influence consumers' intentions to } \\
\text { purchase counterfeit luxury brands. Integrity was noted to } \\
\text { be a strong influence on both attitudes and consumer } \\
\text { willingness to purchase consistently. Both buyers and } \\
\text { non-buyers were tested for their attitudinal differences. } \\
\text { Status consumption and materialism did not play a role in } \\
\text { influencing attitudes or willingness to purchase. }\end{array}$ \\
\hline
\end{tabular}


Table 2 Materialism in Counterfeit Literature (Continued)

\begin{tabular}{lcc}
\hline Author(s) & Year & Short description \\
\hline & & Survey among 230 respondents in Indonesia. Analytical \\
& & results indicated that Indonesians with high materialism \\
Lu and Lu & 2010 & $\begin{array}{l}\text { and relativism were more likely to engage in actions that } \\
\end{array}$ \\
& were questionable but legal. \\
\hline
\end{tabular}


